\title{
Manuscript Collections: The Iowa Women's Archives
}

\author{
SHARON M. LAKE
}

The Annals of Iowa has had a tradition of publishing descriptions of manuscript collections that shed significant light on Iowa history. I am happy to revive that tradition with this valuable guide to collections on the political activism of Iowa women at the Louise Noun-Mary Louise Smith Iowa Women's Archives at the University of Iowa Libraries.-Editor

THE SIGN is easy to miss unless you know to look for it. Even then, first-time visitors wonder if it is accurate as they follow the arrow and turn down a nondescript hallway lined with students' lockers and bulletin boards. Yet once the Louise NounMary Louise Smith Iowa Women's Archives (IWA) is located and entered, a wealth of information is revealed behind that modest sign and door. Topics as diverse as women's sports, civil rights, the Republican Party, environmental issues, economic policy, or radical feminism can be researched in the political collections of the IWA. The purpose of this essay is to acquaint historians with the scope of the IWA's holdings, particularly the collections on the political activism of Iowa women, and to invite researchers to consider the broad range of scholarly inquiries these primary documents can support.

My involvement with the IWA, housed on the third floor of the Main Library at the University of Iowa, began in the fall of 1999. I was researching Iowa's passage of one of the first rape shield laws in the nation, and fortunately, one of my professors directed me to the IWA. What a gold mine it turned out to be!

THE ANNALS OF IOWA 63 (Spring 2004). (C) The State Historical Society of Iowa, 2004. 
Using documents from several collections, I was able to uncover a full (and fascinating) account of the mid-1970s reformation of Iowa's rape laws. I found out how the effort began, who provided the leadership, and what specific steps were taken to ensure passage of the legislation. The following summer I interned at the IWA, and I have worked with the political collections as a researcher and part-time processor ever since.

The IWA was established in 1992 by two extraordinary women-Louise Noun and Mary Louise Smith. While preparing to write her important book on the suffrage movement in Iowa, Noun had discovered that there were no collections of primary sources for her to use. ${ }^{1}$ That brought home the recognition that as long as women's papers were not in the archives, women would not be in the history books. She raised the issue with her good friend and fellow activist, Mary Louise Smith. Although Noun was a staunch Democrat and Smith a loyal Republican, together they had championed the rights of women throughout their long careers. The two women decided, once again, to take action. Noun sold a Frida Kahlo painting from her personal collection to raise the initial endowment fund for the IWA, and Mary Louise Smith negotiated an agreement with the University of Iowa to provide space and assume administrative responsibility for the collection. At the dedication of the IWA, Smith explained their vision. She and cofounder Noun wanted women's papers to be collected and maintained in their own archives, with their own staff to develop the collections and assist scholars in using them. "Our culture and traditions have allowed our history to be dominated by accounts of men in the business world, industry and labor, in education, in the military, in sports and in politics and public life. Women have, however, played important roles, too, whether or not we have acknowledged them or whether or not we even know their names. ... The Iowa Women's Archives is designed to collect and preserve the stories of these women before they are lost or forgotten."

1. Louise R. Noun, Strong-Minded Women: The Emergence of the Woman-Suffrage Movement in Iowa (Ames, 1969).

2. "Mary Louise Smith's Remarks at the Dedication of IWA," 10/28/1992, IWA history folder. 


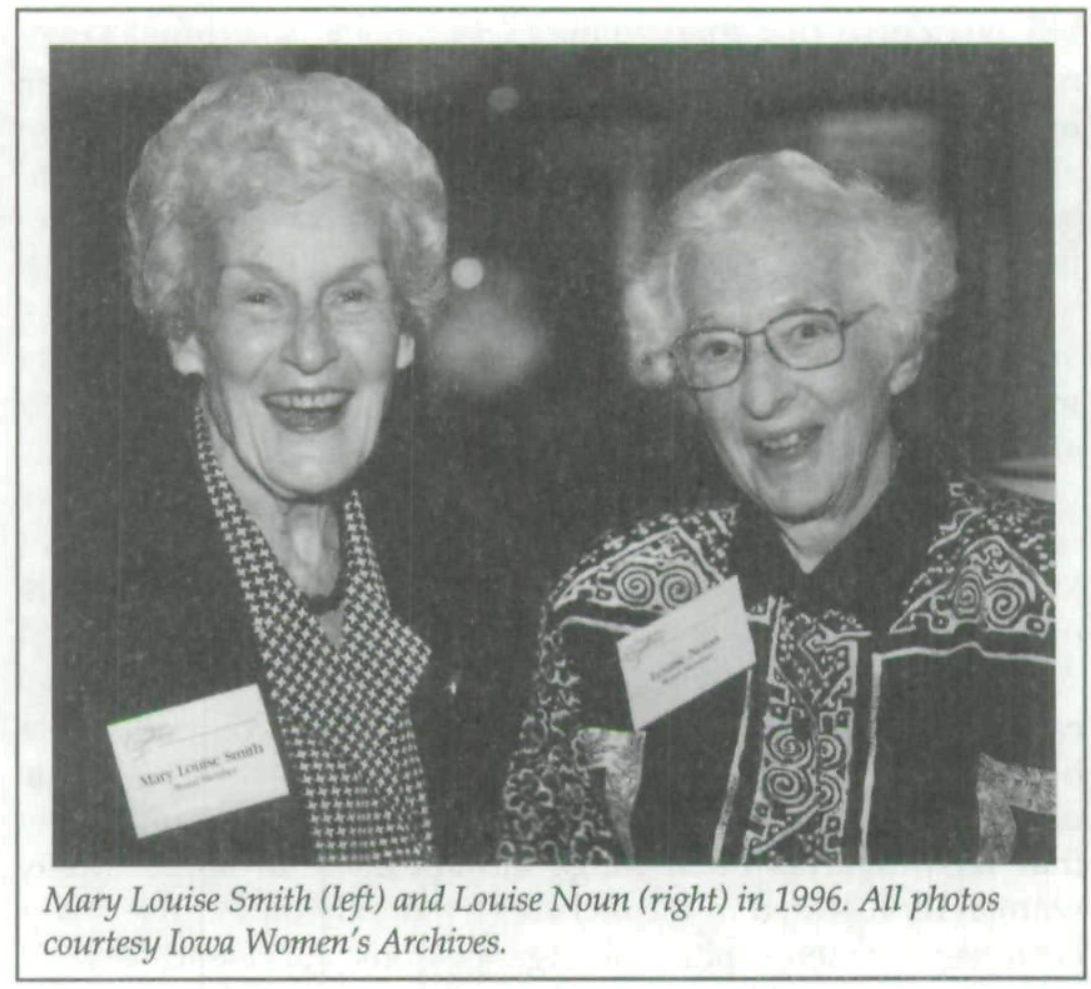

Today, the IWA is the most significant archival resource on the political activism of Iowa women. That is not surprising when one considers that the IWA's cofounders both distinguished themselves through political work. In her memoir, Louise Noun credits her work with the League of Women Voters, which she joined in 1944, as marking "a distinct turning point" in her life. The League "opened a new world for me," Noun recalls - one in which she found herself, for the first time, "not a follower, but a leader." ${ }^{3}$ Noun embraced this public world of community involvement and was one of Iowa's most outspoken and effective champions of women's rights and civil liberties for more than 50 years. Mary Louise Smith's involvement with her local Republican Party in Eagle Grove whetted her appetite for more responsibility as well. She noticed that while women did all the phone calling, canvassing, and mailings, the men set pol-

3. Louise R. Noun, Journey to Autonomy: A Memoir (Ames, 1990), 64, 81, 72. 
icy. "I suppose that sparked me to do some goal setting," Smith recounts. She began working her way up through the ranks in order to have "something to say about the organization and about the programs and about the direction that the party was going. ${ }^{14}$ In 1974 Smith was appointed the first woman chair of the Republican National Committee.

Many of the IWA's initial accessions focused on political activism, thanks to archivist Bob McCown of the University of Iowa's Special Collections Department. Throughout the 1970s and 1980s McCown had sought out the papers of politically active women and women's political organizations. Those collections were transferred to the IWA when it opened. Because of McCown's work, therefore, the IWA started with a strong core of important collections on Iowa women's political work.

The IWA has grown considerably since 1992, and the political collections are only one portion of the IWA's comprehensive holdings. Moreover, while all the collections in the IWA relate directly to the lives of Iowa women, researchers should know that their contents often range far beyond that scope. Many women represented in the archives lived only part of their lives in Iowa; women's political organizations addressed a wide range of issues (racial justice, labor issues, the criminal justice system, reapportionment); and women's papers often shed light on the activities of their male family members, colleagues, and social acquaintances.

Similarly, although the political collections extensively document women's issues such as sex discrimination and reproductive rights, they are not the only issues that can be researched in these collections. The papers of organic farmer Denise O'Brien document her efforts to preserve family farms, promote sustainable agriculture, and encourage women's participation in the development of food policy. The papers of State Senator Mary C. Neuhauser address many issues of state governmentfrom taxes and transportation to criminal justice and economic development. Neuhauser held public hearings on gun control laws, for example, following the 1991 shooting of several members of the Physics Department on the University of Iowa cam-

4. Louise R. Noun, More Strong-Minded Women: Iowa Feminists Tell Their Stories (Ames, 1992), 148. 
pus. She also served on the committee overseeing the development of the controversial Iowa Communication Network (ICN) in the 1990s, and the debates over the role of private enterprise in that public project can be researched in her papers. Struggles for racial justice are documented in the papers of African American women such as Virginia Harper, a leader in the Fort Madison branch of the National Association for the Advancement of Colored People (NAACP) from the mid-1960s to the mid-1990s.

Most of Iowa's women politicians did not plan, or train, to enter the field of politics, and their collections often document their first careers. Iowa's Secretary of State Mary Jane Odell, for example, was a journalist who hosted several popular radio and television programs in Iowa and Chicago for more than 20 years. She resigned from Iowa Public Television in 1979 when format changes drastically reduced her role. Shortly thereafter Governor Robert Ray appointed her Secretary of State following an unexpected vacancy. Odell's collection is a valuable resource for researching the evolution of television journalism, the shifting formats of talk and news programs in the 1960s and 1970s, and the role of women in broadcasting. Lieutenant Governor Jo Ann Zimmerman began her career in nursing and health policy before turning to politics. The expertise Zimmerman brought to legislative issues such as the living will can be more fully understood by examining the papers on her nursing career in her collection.

For other women, politics was a more seamless extension of their careers. Des Moines attorney Roxanne Conlin used her legal expertise to work for equal rights for women, yet her collection documents the full scope of her long and productive legal career, including her work as assistant attorney general (19691976), the cases she handled in private practice, and her 1992 election as the first female president of the American Trial Lawyers Association. The collection of educator, social worker, and Waterloo Human Rights Commissioner Betty Jean Furgerson, who focused her efforts on strengthening the African American community, also documents her service on the Iowa Board of Regents and the Iowa Public Television Broadcasting Board. In an archival collection as large as the IWA's, these examples are just the tip of the iceberg. 
The IWA has more than 90 collections classified under the subject heading, "Women, Politics, and the Law," totaling well over 500 linear feet. ${ }^{5} \mathrm{~A}$ few important collections relate to the woman suffrage movement, but most document events that have taken place since the 1950s. The collections come from all parts of the state: eastern and urban areas are more frequently represented, but small towns such as Newton, Charles City, Spencer, and Red Oak are also represented. Many politically active women grew up on farms or in rural communities before college, employment, or marriage took them to urban areas, and their collections add to our understanding of rural Iowa. ${ }^{6}$ The ideological viewpoints span a wide spectrum, although most espouse the moderately conservative or liberal views of the broad political center. The bulk of the holdings are papers and records. Many collections include at least a few photographs, and some contain audio-visual recordings or artifacts as well. Several collections include oral histories or research notes from journalistic or scholarly projects. ${ }^{7}$ The entire collection can be searched via an excellent Web site that allows researchers to search the holdings by topic or collection name and to access the complete finding aids of all processed collections. ${ }^{8}$

The remainder of this essay presents an in-depth discussion of the contents of the political collections. It is organized into several key categories to highlight the IWA's strengths and to facilitate discussion of the types of scholarship it can support. Each category-second-wave feminism, African American women, political organizations, elected officials, and the woman suffrage movement-includes a discussion of the most significant or un-

5. The collections under this heading directly relate to formal political processes or governmental bodies. In this essay, I range beyond these at times to describe collections that show evidence of activism that aims to alter power relations through cultural or social practices. Overall, the IWA holds more than 600 processed collections.

6. Minnette Doderer, for example, lived on a farm near Holland in her early years; Jo Ann Zimmerman was born and raised on her parents' farm in Van Buren County; and Mary Louise Smith grew up in Eddyville.

7. For oral histories, see "A Political Dialogue: Iowa's Women Legislators," and the papers of Verda Williams, Frances Hawthorne, and Louise Noun. See research notes in the collections of Louise Noun and Margaret Atherton Bonney.

8. Web site at www.lib.uiowa.edu/iwa/. 
usual collections, with descriptions of the individuals or organizations they represent. Throughout the essay, I highlight the local significance and the national connections of this valuable resource.

THE MANY COLLECTIONS documenting the rapidly unfolding second-wave feminist movement, especially during the 1970s, represent a major strength of the IWA's holdings. This rich vein of primary sources on second-wave feminism presents many opportunities for filling historiographic gaps. Activists and historians Rosalyn Baxandall and Linda Gordon have lamented the "lack of scholarly research" on second-wave feminism, especially at the grass-roots level, which, they note, is "difficult to study because it was so big, so decentralized, and often left few records." In the introduction to their recently published collection of primary documents from the women's liberation movement, Baxandall and Gordon note that "very little has been written that examines the movement's breadth and variety." A new study of feminism in Dayton, Ohio, similarly notes that "few book-length histories based on primary-source material have been published on the second wave movement." The collections at the IWA provide documents to remedy that situation.'

Roxanne Conlin's collection is one of the best places to begin research on the political and legal accomplishments of the second-wave women's movement in Iowa. After graduating in 1966 from Drake Law School, where she was active in the Democratic Party, Conlin energetically dedicated herself to the task of securing equal rights for women. In 1973, while serving as assistant attorney general, she attended the first convention of the National Women's Political Caucus (NWPC) in Houston, Texas. Inspired by the potential of this new organization, Conlin quickly organized an Iowa chapter, the Iowa Women's Political Caucus (IWPC), and served as its first chair. Conlin traveled ex-

9. Rosalyn Baxandall and Linda Gordon, Dear Sisters: Dispatches from the Women's Liberation Movement (New York, 2000), 1-2; Judith Ezekiel, Feminism in the Heartland (Columbus, $\mathrm{OH}, 2002)$, ix. For a list of several unpublished studies of local feminist communities, see the bibliographical essay in Ruth Rosen, The World Split Open: How the Modern Women's Movement Changed America (New York, 2000), 424-25. 
tensively throughout the state giving speeches and helping to organize local chapters of the IWPC. She worked with women legislators in Iowa and around the nation to improve the legal status of women and was key to forging alliances between women's groups such as the IWPC and the Iowa Commission on the Status of Women. In 1982 Conlin became the first woman to be nominated by a major party for governor in Iowa, and she ran a strong, although unsuccessful, campaign. Conlin was tireless in her pursuit of equal rights for women and undaunted by the scope of the task. Her role in shaping the agenda of secondwave feminism is well documented in her extensive collection, which is of national, as well as local, significance.

The records of the IWPC illuminate the grass-roots political work of the women's movement in Iowa especially well. The IWPC was the largest state chapter of the NWPC until it was surpassed by Texas and California in 1980, and its effective bipartisanship was touted as a model for other states. Founding member Mary Louise Smith vividly recalls that the IWPC's first convention in Ames in 1973 was "a real emotional high" and the beginning of a "great wave of enthusiasm. ${ }^{10}$ The IWPC pursued an ambitious legislative agenda with great success. In 1974 IWPC members played a critical role in securing passage of one of the first statutes in the nation that forbade inquiries into the sexual history of a rape victim. The IWPC also worked to secure equal access to credit and insurance for women, to improve women's Social Security benefits, and to remove gender bias from many sections of the Iowa code. The IWPC helped elect women to public office, sponsored state and local conferences, held annual meetings, and initiated a Girl's Leadership Camp for high school girls. The IWPC records include important, unpublished academic papers on topics such as sexism in textbooks and in television programs. The collection also includes a number of amusing buttons from the 1970s with slogans such as, "Hire Him! He's got great legs!" and "A man's house is his castle-let him clean it."

The IWPC collection is especially valuable because it includes local, state, and national records that link small-town

10. Noun, More Strong-Minded Women, 151. 
Iowans to the national movement. More than 30 local caucuses had formed by the end of the 1970s, and the IWPC collection contains their membership lists, bylaws, and the newsletters of larger chapters, such as those in Polk and Black Hawk Counties. ${ }^{11}$ In 1975 and 1976, the IWPC sponsored a conference titled "Iowa Woman 2000" in more than 20 mid-sized communities, such as Atlantic and Muscatine. The evaluation forms from these conferences include demographic information about the participants and their comments about the workshops. It is interesting to see how many women suggested that future conferences should include a workshop designed for men! This look at how local women helped to shape, and were shaped by, the women's movement is critical for understanding how the women's movement changed America. It is at the local level that we see how national issues played out. The records of the IWPC are a valuable resource for tracing the reach of feminism and the women's movement into the heartland of America.

The IWPC collection also includes many records related to the National Women's Political Caucus (NWPC). These include agendas, mailings, workshop materials, and papers from the biennial national conventions, as well as NWPC newsletters, steering committee minutes, and audio-cassette recordings of keynote speeches made at the 1977 convention. The IWPC's bid to host the 1975 national convention is documented, and newspaper clippings discuss Roxanne Conlin's narrow loss in her 1975 run for chair of the NWPC. The race led to a partisan feud within the IWPC, when Mary Louise Smith supported Conlin's Republican rival. Conlin's high profile within the national organization and Smith's power within the Republican Partycoupled with the size and successes of the IWPC - brought national leaders such as Bella Abzug, Gloria Steinem, and Billie Jean King to Iowa and IWPC events. The IWPC collection helps place Iowa within the national women's movement.

11. There is also a separate, important collection of the Polk County Women's Political Caucus (PCWPC). Many of the most influential members of the IWPC, including Conlin and Smith, belonged to the PCWPC, and, because it was located in the state capital, Des Moines, it coordinated lobbying efforts, met with Iowa's political leaders, and hosted the visits of national figures. 
Second-wave feminists addressed gendered and racialized power imbalances through educational processes, cultural expressions, and social structures. The IWA has many collections documenting their initiatives, especially at the local level. Examples include the papers of the Emma Goldman Clinic, Iowa City's nationally recognized feminist health care clinic; feminist and lesbian publications, including a complete set of Ain't I a Woman? (published in Iowa City in the early 1970s) and the original mock-ups of the nationally renowned Greasy Thumb Auto Mechanics Manual for Women (published by the Iowa City Women's Press in 1976); the records of the Women Against Racism Committee, which sponsored several regional conferences in Iowa City in the early 1980s; and the records of the Women's Resource and Action Center (WRAC), which include a national collection of radical feminist publications from the WRAC's Sojourner Truth Library.

The papers of individual activists make important contributions to the study of second-wave feminism at the local level. They provide evidence of the specific events women organized and attended, the informal networks that sustained the movement, and the wide range of issues addressed by feminists. Jo Rabenold, known in Iowa City as the "roving lesbian," saved a broad range of publications, newsletters, posters, pamphlets, and flyers relating to gay and lesbian issues and events. Her collection includes single issues of many national publications and a more complete set of the Iowa-based Better Homes and Dykes. Rabenold's collection provides a good look at the social activities and political concerns of the women's and lesbian communities in Iowa City.

University of Iowa administrator Nancy ("Rusty") Barceló's papers highlight the intersection of community activism and professional work on issues of gender, race, sexual orientation, and class. Barceló moved to Iowa to attend graduate school at the University of Iowa in 1970 and was a founding member of the Chicano-Indian-American Student Union in $1971 .{ }^{12}$ During the 1980s Barceló worked as assistant dean for academic affairs at the University of Iowa; after she was promoted to assistant

12. The Center's current name is the Latino Native American Cultural Center. 
provost in 1995, her duties included recruiting and retaining minority students. Barceló was active in many organizations, including the Women Against Racism Committee; the Lesbian, Gay, Bisexual, and Transgender Student, Faculty and Staff Association at the University of Iowa; and organizations addressing the concerns of the Latino community. Her papers especially illuminate Latina perspectives on higher education and the feminist movement. Barceló left Iowa in 2001 to accept the position of Vice President for Minority Affairs at the University of Washington, but she remains involved in the state she called home for more than 20 years. In 2002, when she participated in the IWA's tenth anniversary conference, Barceló thrilled her audience with the dramatic announcement that she intended to help fund a project to collect the papers Latinas for the IWA. The enthusiastic reception of Barceló's announcement encouraged the IWA to focus on this project. Funding was sought, and the $\mathrm{Mu}-$ jeres Latinas project was recently launched. ${ }^{13}$

Many women who were active in the women's movement belonged to or supported a wide variety of overlapping and interlocking groups, including labor, peace, civic, professional, women's, educational, partisan, and civil rights organizations. IWA cofounder Louise Noun's collection is one of the best examples of this because of the length and breadth of her engagement in public affairs. During her long career, Noun was a founding member and president of the Des Moines chapters of both the League of Women Voters (LWV) and the National Organization for Women (NOW), president of the Iowa Civil Liberties Union (ICLU), an art collector and member of the Des Moines Art Center board, an active Democrat, a historian and writer, a philanthropist, a civil rights activist, and an agitator to the end of her long and productive life. ${ }^{14}$

Noun's path was not easy to foresee. She began life as the well-heeled daughter of a wealthy Jewish businessman, and her

13. See www.lib.uiowa.edu/iwa/mujeres.htm for details on this project.

14. Noun ended her life in 2002 at the age of 94 . She had asked Des Moines Register editorialist Rekha Basu to write an article after her death explaining Noun's support for the right to choose to die. Basu honored her request; the article was published on August 24, 2002, the day after Noun died. It was her final act of public advocacy. 
mother raised her to be an artist. Noun graduated from Grinnell College in 1929, received an M.A. in art history from Harvard in 1931, married dermatologist Maurice Noun in 1936, and began the life of a "doctor's wife and society matron. ${ }^{15}$ But the role did not suit her, and Noun gradually shed it to make her own way through a world that offered little encouragement for strong and independent-minded women.

Noun's scrapbooks tell the story of her evolution as an activist. Her work with the LWV, begun in 1944, was the first step on the path to community activism. Over the next 58 years she would champion many causes. She became involved with the ICLU in the early 1960 s and was president during the years of litigation on the nationally renowned Tinker black armband case. The ICLU supported the students' right to wear black armbands to school to protest the Vietnam War, and the organization established a legal defense fund to pay court costs while Noun and her brother personally paid the attorney fees. The case eventually went to the U.S. Supreme Court. Its landmark decision in 1969, Tinker v. Des Moines Independent Community School District, found in the students' favor. ${ }^{16}$ In 1972 Noun cochaired (with civil rights activist Edna Griffin) Iowa's committee to support African American Congresswoman Shirley Chisholm's bid for the Democratic presidential nomination. And, in 1974, during Noun's tenure as president, the Des Moines branch of NOW denounced the sexist practices of the United Way. A detailed examination of United Way's decisions had revealed large discrepancies in the levels of funding for girls' and boys' organizations and other objectionable practices. NOW released this information to the public and carried on a public campaign against United Way for several years. These activities are well documented in Noun's scrapbooks and papers. Insights into many political movements and organizations can be gleaned

\footnotetext{
15. Noun, Journey to Autonomy, 60.

16. The most frequently quoted phrase of Justice Fortas's opinion is his statement: "It can hardly be argued that ... students or teachers shed their constitutional rights to freedom of speech or expression at the schoolhouse gate." University of Northern Iowa history professor John W. Johnson has written a book-length treatment of the case. See John W. Johnson, The Struggle for Student Rights: Tinker v. Des Moines and the 1960s (Lawrence, KS, 1997).
} 
through the papers of this one remarkable woman. Multiply that by the number of collections housed at the IWA and you will begin to appreciate the richness of this archive.

THE COLLECTIONS documenting the political work of African American women are another strength of the IWA. Historians of the civil rights movement have pursued several lines of inquiry in recent years, including the initiatives of local activists and organizations, the contributions of women, and a re-periodization of the movement as a continuous struggle that neither began with the Montgomery bus boycott in 1956 nor ended with the passage of the Voting Rights Act in $1965 .{ }^{17}$ Collections in the IWA provide evidence that scholars can use to contribute to these efforts, as well as to investigate the connections among race, gender, and class that also have been illuminated in recent years. Many of the collections are small-some are tiny-but they still provide important traces that give researchers starting or connecting points for uncovering the ways African American women in Iowa resisted racism and strengthened their communities. ${ }^{18}$

A good example is the collection of Edna Griffin, who has been called "the Rosa Parks of Des Moines." In 1948 Griffin successfully challenged the segregated lunch counters at Katz Drugstore in downtown Des Moines. On the fiftieth anniversary of that victory, Griffin received the first annual Community Trailblazer Award from the governor, and the building in which Katz Drugstore had been housed was renamed in her honor. Griffin was recognized not for that one action alone, but for a

17. Peniel E. Joseph, "Black Liberation Without Apology: Reconceptualizing the Black Power Movement," The Black Scholar 31 (Fall/Winter 2001), 2-19.

18. Historian Deborah Gray White has noted several reasons for the relatively sparse archival holdings on African American women. These include a lack of papers and a lack of trust. Black women often did not save their papers, she notes, because "they have grown used to being undervalued and invisible." And black women have been "reluctant to donate their papers" - especially personal ones-because of the "adversarial nature of the relationships that countless black women have had with many public institutions." For both reasons, White emphasizes the importance of oral histories as sources of information about the lives of African American women. See Deborah Gray White, "Mining the Forgotten: Manuscript Sources for Black Women's History," Journal of American History 74 (1987), 237-42. 
long and rich life of community activism. Although Griffin's collection contains only a handful of newspaper clippings and newsletters, other IWA collections can be combined with it to explore Griffin's life more fully. The Iowa Women's Hall of Fame collection includes her nomination papers, and Verda Williams's papers include a 1985 interview with Griffin. ${ }^{19}$

The collection of Virginia Harper, who helped integrate Currier Residence Hall at the University of Iowa in 1946, documents her long history of leadership in the fight for racial justice in Iowa. It includes many editions of the newsletter of the Fort Madison branch of the National Association for the Advancement of Colored People (NAACP), which Harper wrote and produced in the mid-1960s. In each edition, Harper reported on local instances of racial discrimination and exhorted the African American community to boycott local businesses that refused to hire minorities. Harper's collection documents her work with NAACP attorneys over an eight-year period (late 1960s to mid1970s) to successfully challenge the routing of Highway 61 through a minority neighborhood. Harper served as president of the Fort Madison NAACP from 1978 until her death in 1997 and was active in a wide range of church and civic organizations. She did volunteer work at the state penitentiary in Fort Madison and was the first African American woman to serve on the Iowa Board of Parole. Harper's family was prominent in Fort Madison's African American community, and her collection includes papers related to her father, Dr. Harry Harper, an earlier president of Fort Madison's NAACP branch. ${ }^{20}$

In addition to holding the papers of civil rights activists, the IWA also holds two small collections related to African American women who held public office in Iowa. Jane Burleson worked at

19. After working at NBC-TV in New York in the 1970s, radio announcer and TV producer Verda Williams returned to Des Moines and, in 1985, wrote and produced the TV special, "Voices Seldom Heard." Williams interviewed 12 prominent African American women and men from Des Moines, including Edna Griffin and Marguerite Cothorn, who also has a small collection in the IWA. The interviews span much of the twentieth century, some recalling childhoods in the 1920s and 1930s. Verda Williams's collection includes manuscripts of the interviews and a videotape of the program.

20. Dr. Harper's papers are in the University of Iowa Libraries' Special Collections Department. 
the Hormel plant in Fort Dodge for more than 30 years and was the secretary of her local union. In 1983 Burleson became the first woman-and the first African American-elected to the Fort Dodge City Council. She served until 1997. Burleson's papers consist largely of newspaper clippings about her work and several photos of her with state and national political figures. At the top of an old newspaper clipping of Hosea Williams speaking at the 1968 Poor People's March in Washington, D.C., Burleson wrote, "I was there." University of Northern Iowa professor of social work Ruth Anderson was elected to the Black Hawk County Board of Supervisors in 1988. Her papers consist mainly of newspaper clippings and transcripts of her speeches, including her 1986 keynote address, highlighting global issues, delivered at the Fifth Annual Quad Cities Women's Conference. Anderson was inducted into the Iowa Women's Hall of Fame in 1982 and the Iowa African American Hall of Fame in $1996 .^{21}$

Scholars have demonstrated that women's political activism cannot be measured solely by their participation in formal political processes. It is especially important to trace the political activism of African American women outside such channels because "when black women moved into the public arena of work and politics they did so under conditions distinct from those that mobilized white women and with different goals and strategies." ${ }^{22}$ African American women's activism has centered on community organizing and education, argue historians Darlene Clark Hine and Kathleen Thompson. ${ }^{23}$ Several small collections demonstrate that African American women in Iowa carried on these traditions. These include the papers of Grace Morris Allen Jones, who ran the Grace M. Allen Industrial School in Burlington for African American students from 1902 to 1906 and later married Dr. Laurence C. Jones, founder of the renowned Piney Woods Country Life School for black students in Mississippi; and a collection of Elizabeth C. (Betty) Tate, who ran a

21. Anderson tells her own story in Ruth Bluford Anderson, From Mother's Aid Child to University Professor: The Autobiography of an American Black Woman (Iowa City, 1985).

22. White, "Mining the Forgotten," 237.

23. Darlene Clark Hine and Kathleen Thompson, A Shining Thread of Hope: The History of Black Women in America (New York, 1998), 5. 
boarding house for African American University of Iowa students from 1939 to 1969 . Iowa City's alternative high school was recently named for Tate. The IWA also has the papers of Helen Lemme, namesake of Iowa City's Lemme Elementary School. Lemme, a civil rights activist in Iowa City, housed University of Iowa African American students in her home when the dorms were segregated and was active in the League of Women Voters in the 1940 s and 1950 s.

A much larger and richer collection in this vein is that of community and educational activist Lileah Harris. Harris, a Waterloo native, married physician Percy Harris, and the couple settled in Cedar Rapids, where they raised 12 children. Harris's papers contain many details about her years of service on the Washington High School PTA, particularly her work on the Multi-Cultural Non-Sexist Advisory Committee in the 1980s. Harris also served for many years on the board of the Jane Boyd Community House, which provides a wide range of services to low-income individuals. Harris's collection includes copies of her published letters to the editor and newspaper articles that featured Harris, her husband, and other family members. One of the most interesting items in the collection is the transcript of a 1961 meeting of the congregation of St. Paul's Methodist Church held after the Harris family had purchased an empty lot from the church upon which they planned to build a home. The sale had raised a stir: many white residents objected to having a black family move into a white neighborhood, and many church members felt that St. Paul's should not have involved itself in such a controversial matter. The meeting ended in a 460-291 vote in support of the sale, and the Harris family moved into their new home in 1963.

"Black women have a history of striving for education beyond what their gender or their color seemed to prescribe," writes historian Paula Giddings. ${ }^{24}$ The IWA holds the papers of many professional African American women who addressed race and gender injustices and improved their communities. ${ }^{25}$

24. Paula Giddings, When and Where I Enter: The Impact of Black Women on Race and Sex in America (New York, 1984), 7.

25. In addition to those mentioned here, see also the collections of Mary Wood, the first African American executive director of a regional YWCA branch; 


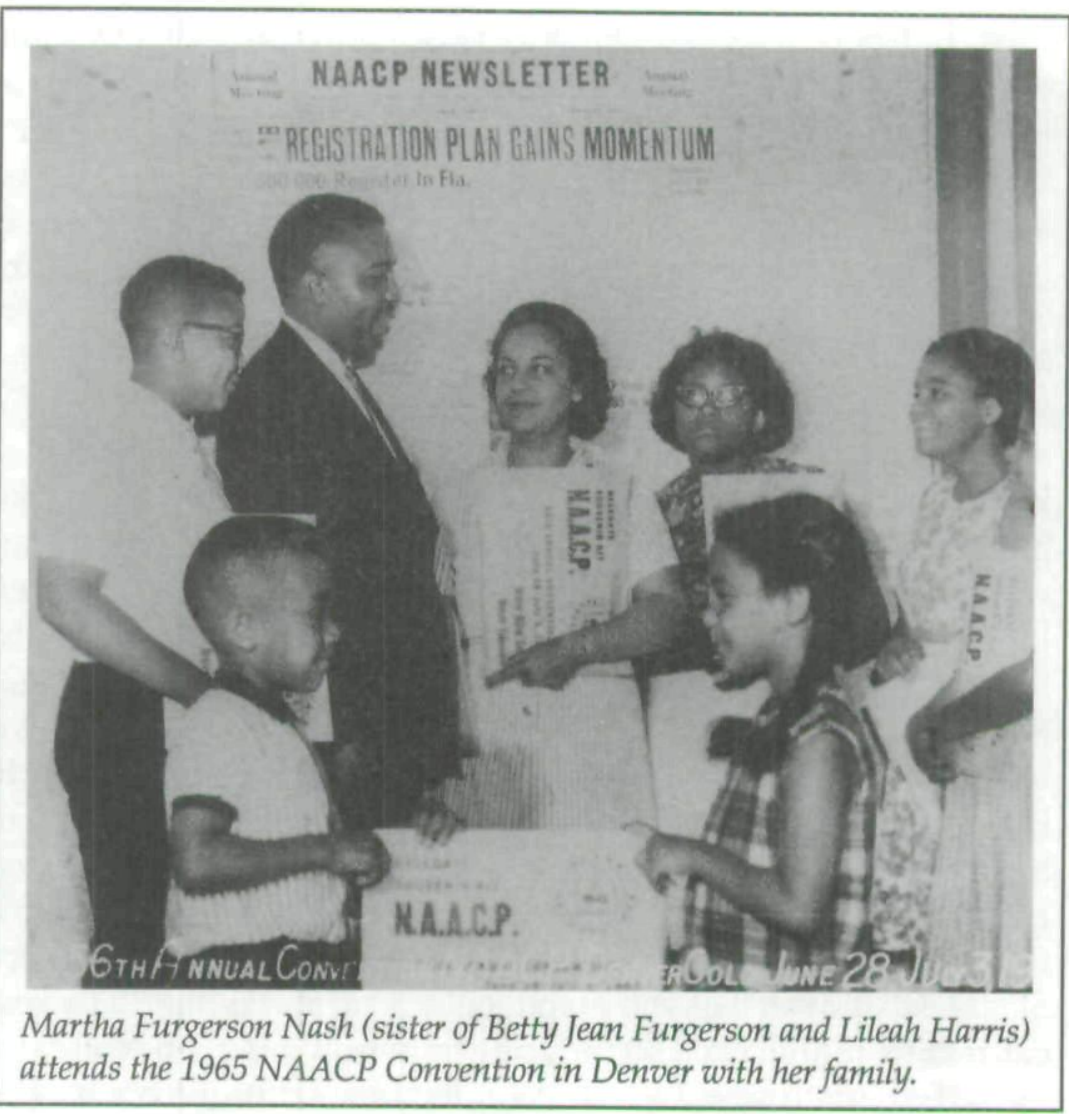

Iowa's first affirmative action administrator, Maude White of Perry, Iowa, received an M.A. from Drake University, where she wrote a thesis on Des Moines's black leadership. White worked for state agencies for many years and was active in a wide range of organizations, including the Des Moines NAACP and the American Association of University Women (AAUW). In 1973 Governor Robert Ray appointed her to the Iowa Civil Rights Commission. White's papers, interestingly enough, give more details on the work she did after retirement, when, at the age of 69, she founded the Des Moines Tutoring Center. White worked for the next eleven years helping youngsters succeed in school.

Gwendolyn Fowler, first African American licensed pharmacist in Iowa, who served in the foreign service in Vietnam in the late 1950s; and Gertrude Rush, the first female African American attorney in Iowa. 
Iowa Board of Regents member Betty Jean Furgerson of Waterloo also used her professional skills to strengthen the African American community. Furgerson (Lileah Harris's sister) received an M.A. from the University of Kansas School of Social Work and worked in several service organizations, including the Waterloo Recreation Center, the YWCA, and Head Start. She served on the Waterloo Human Rights Commission (19741992), and on the Iowa Public Television Board (1988-1995). Her leadership and service earned her the esteem of her colleagues and community. Her collection documents her contribution to many projects, such as a conference on interracial adoptions, and includes hard-to-find studies of minority students in higher education. $^{26}$

Women introduced "a new vision of active citizenship," historian Sara Evans has written, through their work in "voluntary associations located between the public world of politics and work and the private intimacy of family." ${ }^{27}$ The Young Women's Christian Association (YWCA) has been one such association. Since the mid-twentieth century, the YWCA has championed racial justice, but African American women had to struggle for full participation within the organization for many years. The Greater Des Moines YWCA collection illuminates the paradoxical results of the YWCA's policies on race relations in the early twentieth century. It includes the records of the Blue Triangle Club, a division of the YWCA organized in 1919 for African American women. They are a treasure. The Blue Triangle Club, housed in its own facility, sponsored many cultural, educational, and social events. Program notes show that even someone as notable as Langston Hughes read his poetry there in 1932. Several scrapbooks document the club's many activities, and the collection includes membership lists, a short club history, and minutes of the interracial Committee on Colored Work, which met regularly in the 1920s and 1930s. In 1947 the

26. See also the collection of Frances Hawthorne, who interviewed Furgerson in 1992 for her book, African-American History in Iowa: A Chronicle of Contributions, 1830-1992 (Des Moines, 1992). Hawthorne also interviewed Marjorie Marsh, who has a small collection in the IWA.

27. Sara M. Evans, Born for Liberty: A History of Women in History (New York, 1997), 3. 
national YWCA fully integrated all aspects of the YWCA, and the Blue Triangle Club ceased to exist.

Finally, information on the women's interracial "Know Your Neighbor" panel, organized in Des Moines in the 1960s, can be found in two small collections of panel members Arlene Roberts Morris and June Goldman. Morris was the first African American psychologist to be licensed by the state of Iowa. Goldman, a Japanese American born and raised in Kobe, Japan, moved to the United States to live with her grandparents during World War II. Their collections include the panel's bylaws and several articles written about it. The panel was composed of 13 middleclass women who participated in events such as the Burlington United Nations Days to promote racial harmony through education and interaction. The "Know Your Neighbor" panel is a wonderful example of a local response to the national problem of racism.

THE IWA holds the records of many women's political organizations. These include state and local chapters of multi-issue, national organizations such as the League of Women Voters (LWV), the National Organization for Women (NOW), and the Women's National Political Caucus (NWPC), as well as the records of several Iowa organizations focused on the Equal Rights Amendment (ERA). Organizational records make a valuable contribution to the story of women's political activism in several ways. First, they document the continuity of activism and are especially useful for tracing it during periods of "abeyance." ${ }^{28}$ Historians have now revised the earlier view, for example, that feminism disappeared following the ratification of the Twentieth Amendment in 1920, based, in part, on evidence from organizational documents. Organizations, even if small or low-key, provide the framework and resources for public action and are key to tracing the roots of movements for social change. ${ }^{29}$ Second,

28. Verta Taylor, "Social Movement Continuity: The Women's Movement in Abeyance," American Sociological Review 54 (1989), 761-75.

29. For two books that make this case persuasively, see John D'Emilio, Sexual Politics, Sexual Communities: The Making of a Homosexual Minority in the United States, 1940-1970 (Chicago, 1983); and Aldon Morris, The Origins of the Civil Rights Movement: Black Communities Organizing for Change (New York, 1984). 
organizational records often illuminate the existence of informal networks through their membership lists, newsletters, and meeting minutes. Third, they provide information about individual members who may not have left many records of their own. Finally, the collections of state and local chapters often contain papers of the national organization, and sometimes papers of other state chapters as well. These collections help to situate Iowa's political organizations within a broader context.

The League of Women Voters of Iowa (LWV-IA) records are among the IWA's largest collections. They include an unbroken record of the minutes, newsletters, and activities of the statewide organization founded in 1920, as well as extensive papers of its many local chapters. Many of Iowa's most effective political women-including Louise Noun, Mary Louise Smith, Minnette Doderer, and Mary Neuhauser-began their political activism as League members. The LWV is a highly structured organization; both state and local chapters are responsible for fulfilling its mission of improving government. In fact, the Cedar Rapids chapter was placed on probation in the mid-1940s after visitors from the state organization determined that it seemed to exist mainly for "social purposes" and was not really engaged in "League work." ${ }^{130}$

One of the most ambitious projects the LWV-IA conducted was an in-depth study on the issue of reapportionment, which was receiving attention nationwide in the late 1950s and early 1960s. In Iowa and many other states, residents of rural districts enjoyed substantially greater proportional representation in the state legislature than residents of urban districts. The LWV-IA campaigned hard for representation based on population density, not geographic area. Reapportionment came to Iowa, as it did to all states, following the 1962 U.S. Supreme Court decision, Baker $v$. Carr, which held that state representative districts needed to demonstrate attention to population equality. The LWV-IA papers contain extensive documentation of the LWV-IA's involvement with this issue.

Local organizational records are especially valuable because they demonstrate the socially embedded complexity of political

30. Records of LWV-IA, box 23, IWA. 
issues. When issues are addressed on the state or national level, they are often abstracted from their social context and analyzed in general or broad terms. Local records, however, allow us to examine how issues play out in specific communities. The Johnson County/Iowa City NOW (JC/IC NOW) records, for example, document the group's efforts in the late 1970s on behalf of two lesbian mothers in child custody battles and its demonstrations at a local theater to protest the screening of Dressed to Kill. I have used this collection to research the nationally publicized 1979 sex discrimination lawsuit of Iowa City's first female firefighter, Linda Eaton. The JC/IC NOW established a legal fund on Eaton's behalf, raised money locally and through state and national NOW networks, and coordinated press relations as events unfolded. Their support was a significant factor in Eaton's successful lawsuit.

The records of several organizations that worked both for and against the Iowa Equal Rights Amendment (ERA) are housed in the IWA. The national ERA was quickly ratified by the Iowa legislature in 1972, but opposition had mobilized by the time the state ERA was on the ballot. And although the state legislature approved the amendment twice, it lost the popular vote both times, in 1980 and $1992 .{ }^{31}$ Several excellent books have been published on the failure of the national ERA, but few scholarly studies have focused on state ERA campaigns. ${ }^{32}$ The IWA has ample documents to support such work for Iowa.

The first organization formed in Iowa to focus on the ERA was Iowa Women Against the ERA, which got started in the mid-1970s. Its small collection consists mainly of literature from the Eagle Forum, a national anti-ERA organization headed by Phyllis Schlafly. This group deserves historical attention for its role in blocking passage of the Iowa ERA. Although it is a pity the collection is not larger, it provides a good starting point.

31. Iowa law requires a constitutional amendment to be ratified by two successive legislatures and then by the voters at large.

32. The most frequently cited are Mary Frances Berry, Why ERA Failed: Politics, Women's Rights, and the Amending Process of the Constitution (Bloomington, IN, 1986); Jane J. Mansbridge, Why We Lost the ERA (Chicago, 1986); and Donald G. Mathews and Jane Sherron De Hart, Sex, Gender, and the Politics of ERA: A State and the Nation (New York, 1990). Mathews and De Hart cover the fight over the national ERA in the state of North Carolina. 
The records of the Iowa ERA Coalition, which spearheaded the 1980 effort to pass the ERA, are an excellent resource for investigating the grass-roots political activism of second-wave feminism. The collection documents a statewide caravan that visited every one of Iowa's 99 counties. It includes membership lists of each county ERA organization, details about the specific events planned for each stop, and the names of participating local politicians. Press clippings in the collection document the increasingly passionate public debate, and cover the formal debate between the leader of the national Stop ERA campaign, Eagle Forum president Phyllis Schlafly, and Iowa ERA Coalition chair Peg Anderson. ${ }^{33}$ The records in this collection document the participation of a wide range of church, labor, professional, and political organizations in the campaign to pass the ERA. It is a terrific look at the anatomy of a late 1970 s progressive coalition.

Three smaller collections document the unsuccessful 1992 effort to pass the state ERA. The Des Moines-based "ERA Iowa 1992" collection includes a statewide survey conducted by a Des Moines marketing firm in early 1992. The survey showed that most voters supported the ERA. "ERA Iowa 1992" focused on developing an effective media strategy to counter the fears circulated by ERA opponents. The collection includes anti-ERA literature, which group members studied to craft their responses. The collection of their affiliate, the Johnson County ERA Coalition, includes one of the Stop ERA campaign's most frequently used videos: Stop ERA by Phyllis Schlafly.

Because the Iowa ERA had significance for the ongoing efforts to pass a national ERA, the Feminist Majority Foundation took an active role in the 1992 ERA campaign. When misunderstandings arose within ERA Iowa 1992, the Feminist Majority Foundation and Iowa NOW funded a separate organization, the Iowa Women's Equality Campaign, whose activities, including hosting a visit from former NOW President Eleanor Smeal, are documented in a small collection. Although Iowa's ERA fared better in 1992 than it had in 1980, it was still soundly defeated. The loss was a blow to state and national efforts for women's

33. Anderson was a longtime Republican Party activist from Waterloo. The IWA also holds her papers, which mainly document her two years as the president of the IWCP in the mid-1970s. 
equality. The Feminist Majority Foundation commissioned a study of the campaign and published a report in December 1993, which is in the IWA library.

Finally, the archives hold the records of "Add Women to the Constitution," a group that succeeded, in 1998, with what was perceived as a non-threatening approach to gender equality. Their proposal to amend the preamble of the Iowa constitution to read "all men and women" won broad support and was quickly ratified. Proponents attributed their success to two factors. First, the amendment was never called the ERA; second, it included no provisions for legislative action. Many former ERA supporters dismiss this change as largely symbolic in nature, but history shows that legal tools may lie dormant for years before their practical uses are discovered.

IOWA WOMEN have been active members of both the Democratic and Republican Parties. The IWA's collection of Republican Party activists is especially strong; as a group, they provide a good look into the workings and culture of the local, state, and national Republican Party, particularly from the 1950s to the 1970s. These collections include the agendas, platforms, resolutions, and minutes of state and national conventions, as well as records of specific projects of individual women. The most significant of these is the collection of IWA cofounder Mary Louise Smith.

Smith got involved in the Republican Party in the 1950s as a young wife and mother in Eagle Grove. She became Iowa's National Committeewoman in 1964, was elected to the Republican National Committee (RNC) in 1969, and, in 1974, President Gerald Ford appointed her to chair the RNC - the first woman to hold that position. Smith's papers shed light on both the state and national Republican Party during the turbulent period of Watergate and on the conservative turn within the party accompanying the rise of insurgents Barry Goldwater and Ronald Reagan.

Smith was an outspoken advocate of the ERA, a position the Republican Party endorsed during her tenure as chair (1974 1977). Although Smith had not thought of herself as a feminist, 
her outlook had changed fundamentally after she read The Feminine Mystique in 1963, and her commitment to women's rights never wavered. She believed that the ERA was an extension of the Republican Party's philosophy of individual rights, freedom, and responsibility, and she objected to using religious arguments against it. By 1980, however, the Republican Party opposed both the ERA and reproductive rights for women, and Smith found herself on a collision course with her party. She was appointed to the U.S. Civil Rights Commission and served from 1981 to 1983 , but her philosophy did not please the Reagan administration and she was not reappointed. Smith resigned from the RNC in 1984, partly in response to her growing disaffection with its new platform. She subsequently worked with a group called the Republican Mainstream Committee. In the late 1980s Smith also worked with Planned Parenthood and the Iowa Peace Institute. Smith's scrapbooks begin in 1964; they provide insights into both the Republican Party and its various women's clubs. Her extensive collection, one of the IWA's largest, documents her years in Washington, D.C., working with the national party and the Ford administration. Smith remains the only woman ever to chair the Republican National Committee.

The papers of other women who were leaders in Republican women's organizations on local, state, and national levels during the 1950s and 1960s supplement and extend the Smith collection's documentation of women's activism within the Republican Party. These include the collections of Anna Cochrane Lomas of Red Oak, who attended state conventions from the mid-1940s to the early 1970s, and was a delegate to four national conventions; Margaret McDonald of Cherokee County, who cochaired the Iowa Republican Party from 1973 to 1980; Patricia Pardun of Benton County, who was active in the Women's Division of the RNC, the National Federation of Republican Women, and the Iowa Council of Republican Women; and Sue Reed, president of the Iowa Council of Republican Women from 1963 to 1964 and membership chair of the National Federation of Republican Women from 1970 to 1971 . Reed summed up her philosophy in an essay intended to boost recruitment efforts in the party. 


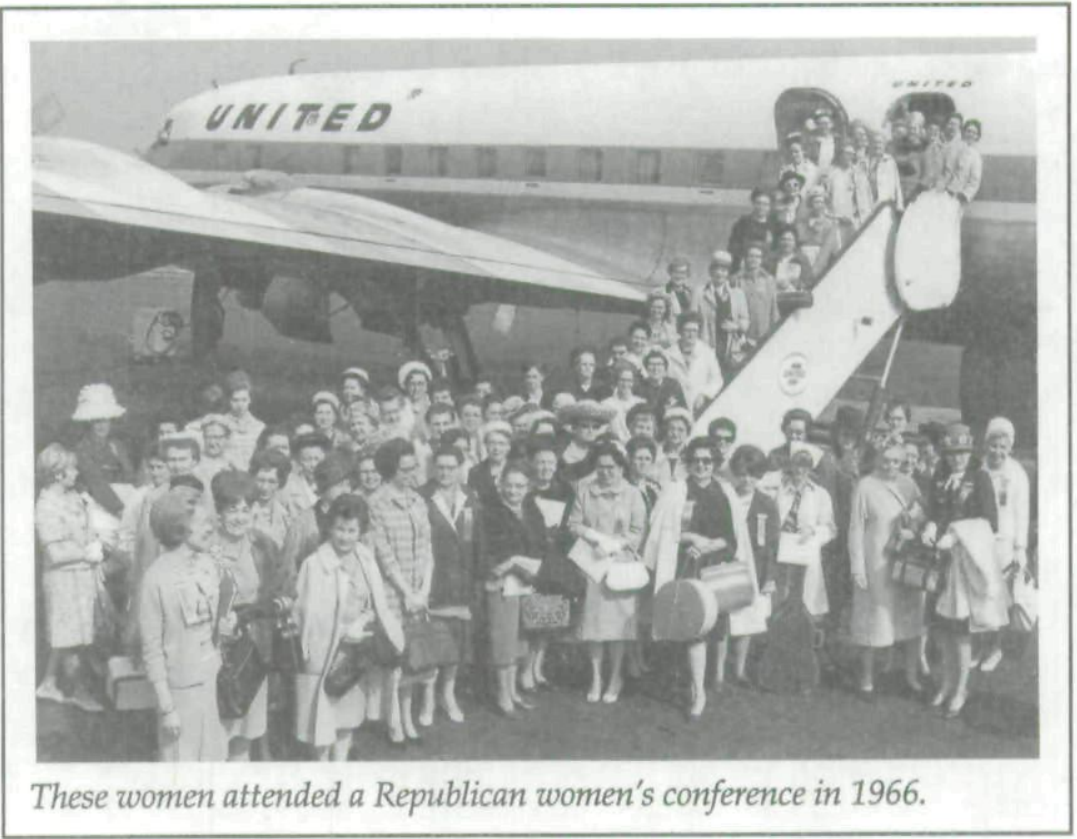

Women must be reminded, she wrote, that they "cannot be a good citizen in this country of ours and not be political."

IN RECENT YEARS, historians have called attention to the limitations of nation-centered history and insisted that more scholarly studies of U.S. history from an international perspective are needed. ${ }^{35}$ In particular they argue that the influence other countries have had on the United States needs to be more fully understood, and that U.S. history needs to be contextualized within world history. Several collections in the IWA could contribute to these efforts. The records of the Des Moines chapter of the Women's International League for Peace and Freedom (WILPF), organized in 1962, include meeting minutes through 1982. The Des Moines WILPF, a small organization that included

34. Sue Reed Papers, box 1, IWA.

35. The essays in Thomas Bender, ed., Rethinking America in a Global Age (Berkeley, CA, 2002), provide a good overview of the arguments. This trend is apparent in other disciplines as well, including American studies. 
male members, conducted many letter-writing campaigns addressing issues such as U.S.-Cuban relations, the plight of political prisoners in Argentina, and the apartheid regime of South Africa. In the late 1970s and early 1980s, WILPF networked with other local peace activists such as Catholic Worker Frank Cordaro and environmental groups such as Citizens United for Responsible Energy to oppose the use of both nuclear energy and nuclear weapons. Flyers and press releases document events held in Des Moines in the early 1980s to commemorate the bombings of Hiroshima and Nagasaki.

The papers of human rights activist and United Nations (UN) advocate Dorothy Schramm of Burlington document her efforts to persuade Iowans that the issues of freedom and security must be addressed at the international level. Schramm was active in the Burlington League of Women Voters (LWV) in the late 1930s. Her papers include notes for a pamphlet she wrote in 1946 for the LWV-IA titled "You are Democracy," which was distributed nationally. Schramm's collection documents her work promoting the UN in Burlington, especially in the 1950s and 1960s, and includes lists of the individuals who attended meetings, with their organizational affiliation. People from a wide range of organizations participated, including the LWV, Veterans of Foreign Wars (VFW), NAACP, Lion's Club, Farm Bureau, Jaycees, and many more. In 1955 Eleanor Roosevelt attended Burlington's UN Day celebration, and the collection includes extensive coverage of that event. Schramm also worked at the state level, and was involved in both the Governor's United Nations Committee and the Iowa branch of the American Association for the United Nations for many years. Her papers include notes for many of her speeches, and document her efforts in the late 1960s to have the United States ratify UN human rights treaties. In 1986 Schramm was elected to the Iowa Women's Hall of Fame.

The papers of Peg Mullen of La Porte City demonstrate the impact of the Vietnam War on one small-town Iowa family. After Mullen's son Michael died in Vietnam in 1970, she and her husband, Gene, were dissatisfied with the U.S. Army's explanation of the cause of his death. Mullen went public with their complaints and became an outspoken opponent of the war. The 
Mullens took out a full-page ad in the Des Moines Register covered with 713 black crosses-one for every Iowa soldier killed in the war. The story of their battle with the army and growing involvement in the antiwar movement was covered by journalist C. D. B. Bryan, who published several articles about the Mullens in The New Yorker in the mid-1970s and later a book titled Friendly Fire. The Mullens received national attention and became a symbol for grieving parents who believed that their sons had died in vain. In 1979 the Mullens' story was depicted in an Emmy Award-winning movie starring Carol Burnett. Peg Mullen later wrote her own book about Michael's death called Unfriendly Fire: A Mother's Memoir.

WOMEN began to seek and win elective office in much greater numbers in the early 1970s. Most historical accounts, however, focus on women's failure to make significant gains at the national or gubernatorial levels and miss the fact that "women forged ahead in local politics. ${ }^{136}$ Nationally, the proportion of women officeholders at the municipal level grew to 23 percent by 1988 and continued rising in the 1990 s. $^{37}$ The papers of local women politicians are a great untapped resource. They reveal the impact women have had on policy making, which is missed when only the national or state level is studied.

The IWA holds the papers of many women elected to city councils, county boards of supervisors, and other local offices. Examples include the papers of Myrtilla Levin, Republican mayor of Newton in the mid-1970s; a small collection of Kim Landhuis, a native of Vietnam who served on the Fort Dodge school board in 1992-93; and the scrapbooks of Thelma Lewis, Iowa City city council member from 1958 to 1963 (and mayor in 1961). Local records reveal stories such as that of Jasper County Supervisor Jeanne Bridenstine, the first woman to become a county commissioner in Jasper County. After being regularly

36. Flora Davis, Moving the Mountain: The Women's Movement in America, Since 1960, Illini Books ed. (Urbana and Chicago, 1999), 186.

37. Sara Evans, Born to Liberty: A History of Women in America (New York, 1997), 314; Glenna Matthews, "Women Candidates in the 1990s: Behind the Numbers," Extensions: A Journal of the Carl Albert Congressional Research and Studies Center (Spring 1995), 10. 
harassed by her male colleagues, Bridenstine started carrying a bright orange notebook to all the meetings and writing down what was said and done. That made her male colleagues think twice!

Local office is also a training ground for politicians and a common route to higher office. Republican Maggie Tinsman of Bettendorf began her career on the Scott County Board of Supervisors before serving in the Iowa Senate, and Democrat Mary Neuhauser served on Iowa City's city council for eight years (two of them as mayor) before running for the legislature. Neuhauser's papers demonstrate how the political skills, experience, and networks she built during her years on the council allowed her to seek and win higher office. She had a track record to run on, dedicated workers to manage her campaign, and a loyal constituent base to support her.

The IWA holds the papers of nearly two dozen women who have served in the Iowa legislature. They are evenly divided between Republicans and Democrats, and most were elected to their first term between 1960 and 1990. The records of Democrat Minnette Doderer of Iowa City are one of the IWA's greatest treasures. Doderer served in the Iowa legislature from 1964 through 2000 (with a two-year break from 1978 through 1980), ran for lieutenant governor twice (1970 and 1978, defeated both times), and served as the first female president pro tempore of the Iowa Senate in 1975. Doderer had been active in the LWV's reapportionment study, and her expertise on that issue was an asset during her first campaign in 1964 because the Iowa legislature was in the process of reapportioning Iowa's legislative districts. Doderer did not consider herself a feminist when she was first elected, but women from all around the state soon began contacting her with their problems. Their letters were an education for Doderer: "That's what made me aware of lives of women and the laws on women, " she stated. "Laws always favored the male.. ${ }^{\prime 38}$ The constituent mail in her collection, therefore, is an important resource for historians. Doderer gradually became one of Iowa's most effective and outspoken advocates for women. She was a key figure in the legislative successes of the IWPC in

38. Noun, More Strong-Minded Women, 164. 


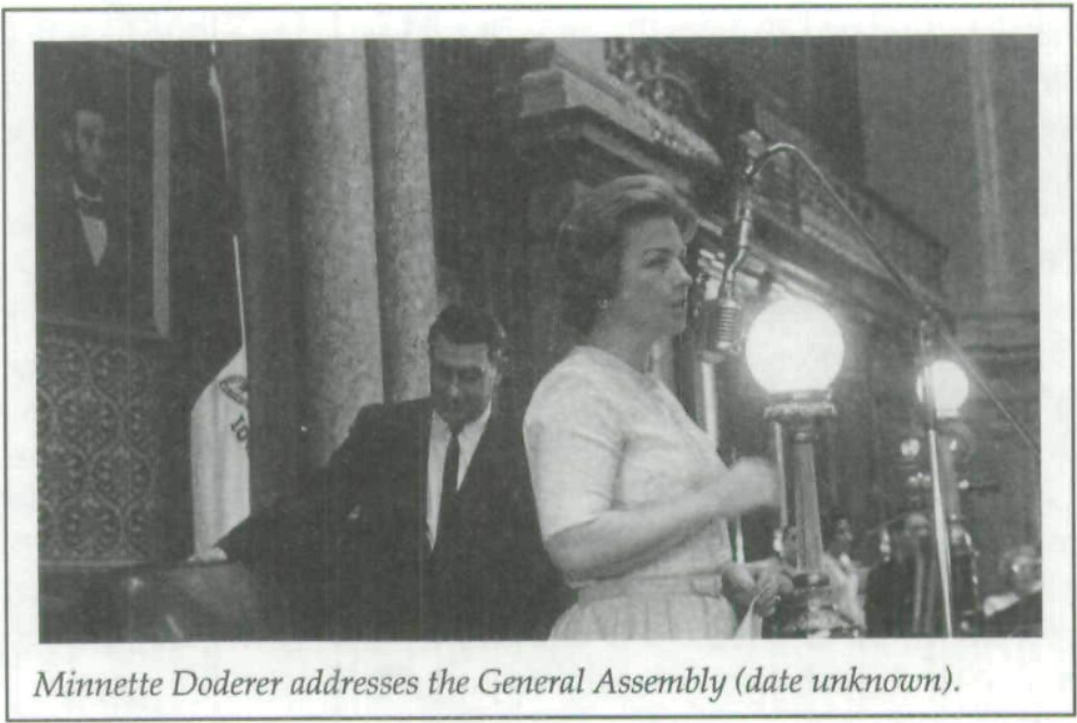

the 1970s, and her collection contains detailed coverage of many issues, such as abortion, the minimum wage, the ERA, Title IX, welfare reform, and comparable pay for women. Doderer, a colorful figure at the statehouse, did not hesitate to speak her mind. When a male colleague opposed the ERA on the grounds that it would force men and women to share public toilets, Doderer retorted that she already shared toilets with men because the Capitol had no women's restrooms on the third floor where her office was located. Doderer's accomplishments and her influence on the Iowa legislature cannot be overstated. Her collection also has national importance because it illuminates the informal national networks of women state legislators and activists, who supplied each other with sample bills and shared strategies for passing them. ${ }^{39}$

Several other legislative collections deserve mention. The papers of Republican Charlene Conklin of Waterloo document her groundbreaking efforts to liberalize Iowa's abortion laws in the pre-Roe 1970s, and her involvement with the acquisition of

39. I came across correspondence in Doderer's collection from women in other states asking for samples of Iowa's new rape laws, for example. This network shows up in the papers of other women as well, such as those of Mary C. Neuhauser and Roxanne Conlin. 
Terrace Hill, which became the governor's mansion. A small collection of Des Moines Democrat Gertrude Cohen, the first Jewish woman in the legislature, contains newspapers clippings about a 1966 resolution she cosponsored asking President Johnson to provide protection for civil rights workers in Selma, Alabama. ${ }^{40}$ The political career of Republican Lena Belle Bock of Garner, who served in the House from 1960 to 1964 and famously remarked that a woman in the legislature needs to "look like a girl, act like a lady, think like a man, and work like a dog," is documented in her scrapbooks. Democratic Senator Beverly Hannon of Jones County, who championed reproductive rights and fought parental notification laws during her tenure from 1985 to 1992, annotated her papers, making her excellent collection even more useful for researchers. ${ }^{41}$ Finally, a rich oral history collection, "A Political Dialogue: Iowa Women Legislators," contains transcripts of interviews with 50 women who served in the Iowa legislature, several of whom also deposited their papers at the IWA. ${ }^{42}$ An interview with June Franklin, one of the few African American women to serve in the state legislature, is in this collection, along with excellent appendixes that list dates served, party affiliations, and biographical information for every woman who served in the Iowa legislature through 1991.

Lastly, several women who held statewide offices have deposited their papers at the IWA. Democrat Jo Ann Zimmerman became Iowa's first female lieutenant governor when she defeated Cedar Rapids Republican and fellow IWPC member Joan Lipsky in a close race in 1986. Zimmerman had entered politics by winning a seat in the legislature in 1982 after a long career in health care. Zimmerman's tenure as lieutenant governor (19861990) was particularly frustrating because she served with a

40. Minnette Doderer also recounts Cohen's pivotal role in making birth control available to women on welfare in 1965. See Noun, More Strong-Minded Women, 164.

41. Hannon vigorously opposed U.S. policy in Central America in the 1980s, and her collection documents 1986 citizen hearings as well as two trips Hannon made to look into the advisability of sending an Iowa National Guard medical unit to Honduras.

42. These include Kay Chapman, Betty Jean Clark, Gertrude Cohen, Charlene Conklin, Minnette Doderer, Beverly Hannon, Patricia Harper, Sonja Larsen, Jean Lloyd-Jones, Mary Neuhauser, and Janis Torrence-Laughlin. 
Republican governor, Terry Branstad, and, Zimmerman complained, she had a hard time getting him to meet with her. Democrat Bonnie Campbell, Iowa's attorney general from 1990 to 1994, moved to Iowa in 1974 to work on Senator John Culver's staff. During her tenure as attorney general, Campbell earned a national reputation for her work on behalf of victims of domestic violence, and in 1995 President Bill Clinton appointed her the director of the Violence Against Women Office in the U.S. Department of Justice. Campbell's papers consist largely of the many speeches she delivered during the 1990s in support of the Violence Against Women Act.

THE IWA holds a small but valuable group of collections that would be useful to researchers interested in the woman suffrage movement. The small collection of Ella Bushnell-Hamlin, who crafted her surname by combining the surnames of her parents after she divorced her husband, contains many newspaper clippings on women's rights. The collection of Jennifer Riggs Cosson of Audubon contains copies of speeches she gave in support of women's rights in Iowa both before and after suffrage, as well as many essays she published. In addition, the collections of Louise Noun and historian Margaret Atherton Bonney include their valuable research notes on the woman suffrage movement in Iowa. Of particular interest in Noun's papers is information on one of Iowa's most important women's rights activists-Annie Savery-while Bonney's notes include many references to the important work of suffragist Mary Jane Whitely Coggeshall. ${ }^{43}$ Finally, copies of suffragist Amelia Bloomer's correspondence, made from the originals in the Council Bluffs Public Library, would be invaluable for anyone researching Bloomer or the suffrage movement.

THE POLITICAL COLLECTIONS at the Iowa Women's Archives have begun to receive regular use by undergraduates, graduate students, scholars, journalists, and nonfiction writers.

43. Noun's book on Savery, Leader and Pariah: Annie Savery and the Campaign for Women's Rights in Iowa (published by the IWA in 2002), was completed shortly before her death. 
Researchers have delved into the ERA struggles, abortion and reproductive rights, the impact of Title IX on women's sports, women's labor activism, African American history, radical feminism, the activism of Republican Party women, and the work of Iowa's women legislators. ${ }^{44}$ Despite all of these exciting projects, the IWA still has an abundance of primary sources that have received little scholarly use and hold many opportunities for important scholarship on the political activism of women in Iowa. Biographies of key figures have not been done; Louise Noun and Mary Louise Smith are obvious choices, but Minnette Doderer, Edna Griffin, and Roxanne Conlin are also prime candidates for such scholarship. Evidence in the IWA's collections could help construct explanations about women's political work and explore the issues that draw women to a realm they have not been trained to think of as their own. Local case histories could be written using these records; these are important not only for the history of Iowa, but because scholars rely on them to construct larger synthetic arguments and support broad conclusions about cultural patterns and social trends.

The political activism of women has reshaped the world. It also changed the women themselves. I have been struck repeatedly by the number of women who state that they became feminists through their work in the political arena. Their realization -that women have a specific relationship to social and political power structures - brought women together for a common purpose. In her remarks to the University of Iowa Foundation's board of directors, Mary Louise Smith noted that although she and Louise Noun were "very different in our partisan loyalties

44. Ph.D. dissertations include Catherine E. Rymph, "Forward and Right: The Shaping of Republican Women's Activism, 1920-1967" (Ph.D. diss., University of Iowa, 1998); Suzanne O'Dea Schenken, "Legislators and Politicians: Iowa's Women Lawmakers" (Ph.D. diss., Iowa State University, 1992 - and published under the same title by Iowa State University Press in 1995); Richard Breaux, "'We must fight race prejudice even more in the North': Black Higher Education in America's Heartland, 1900-1940" (Ph.D. diss., University of Iowa, 2003); and Shelley M. Lucas, "Courting Controversy: Gender and Power in Iowa Girls' Basketball" (Ph.D. diss., University of Iowa, 2001). Grinnell College undergraduate Dan Itzkowitz, working under the direction of Professor Victoria Brown, used IWA collections to write "How Did Iowa Coalitions Campaign for the ERA in 1980 and 1992?" which was accepted on the Web site, "Women and Social Movements" <womhist.binghamton.edu/iowaera/intro.htm>. 
and affiliations," they shared "a strong conviction of the need for a repository for the histories and work of Iowa's women. ${ }^{\prime \prime 45}$ Because of their vision-and their ability to work together to achieve it-historians have a wealth of primary sources to use to investigate women's political activism. Historians Jane S. De Hart and Linda K. Kerber recently wrote, "One of the most effective ways in which dominant groups maintain their power is by depriving the people they dominate of the knowledge of their own history." ${ }^{\prime 46}$ The purpose of the IWA is to ensure that Iowa women's participation in public life is fully explored and fully revealed, so that women can claim their rightful place in the world.

Louise Noun-Mary Louise Smith Iowa Women's Archives

Third Floor, Main Library, The University of Iowa

Iowa City IA 52242-1420

phone: 319-335-5068

URL: www.lib.uiowa.edu/iwa

Hours: Monday-Friday, 9:00 a.m.-Noon, 1:00-5:00 p.m.

45. Remarks for the University of Iowa Foundation Board of Directors, 4/12/ 1991, IWA history folders.

46. Jane Sherron De Hart and Linda K. Kerber, "Introduction: Gender and the New Women's History," in Women's America: Refocusing the Past, ed. Linda K. Kerber and Jane Sherron De Hart, 6th ed. (New York, 2004), 1. 
Copyright of Annals of Iowa is the property of State of Iowa, by \& through the State Historical Society of Iowa and its content may not be copied or emailed to multiple sites or posted to a listserv without the copyright holder's express written permission. However, users may print, download, or email articles for individual use. 